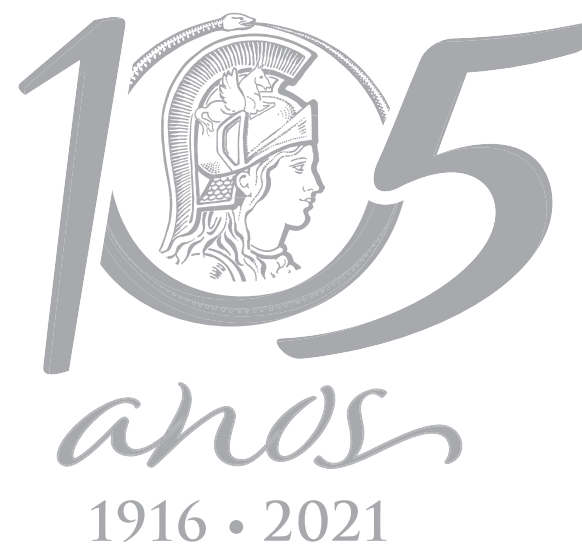

SOIL SCIENCE

\title{
Evaluation of the agricultural potential of the serpentinite rock as a soil remineralizer
}

\author{
JOÃO H.M. VIANA, ANTÔNIO M. COELHO, ANDRÉ THOMAZINI \& MATHEUS P.F. DE \\ CARVALHO
}

\begin{abstract}
Magnesium is one of the essential elements for the plant growth. However, when the supply of magnesium is required exclusively, few economically feasible options are available. Serpentinite represents an alternative source of magnesium, although little is known about its potential and efficiency under tropical soil conditions. This work aimed to evaluate the use of serpentinite as a soil remineralizer, as well as magnesium fertilizer. The study was conducted in a greenhouse, using a completely randomized design, with seven treatments and four replications, as follows: three levels of serpentinite, mix of serpentinite and phonolite, and the controls with dolomitic limestone and without fertilization. Two plant species (Zea mays L. corn hybrid BRS 1055 and Phaseolus vulgaris L. common bean variety BRS - Estilo) and two contrasting soils (clayey and sandy texture), were used in pots. Results showed that serpentinite's free silica and toxic element contents fitted the legal requirements. No statistically significant difference was observed for the plant dry matter weight production in the serpentinite and dolomitic limestone control, as well as in the pure serpentinite and the mix with phonolite treatments. The serpentinite was able to supply and to fullfil magnesium requirements for growth and development of corn and bean plants.
\end{abstract}

Key words: magnesium fertilizers, mineral resources, silicate agromineral, Zea mays L., Phaseolus vulgaris L.

\section{INTRODUCTION}

Magnesium is one of the essential elements for the plant growth, with many functions in metabolic processes (Hawkesford et al. 2012). Its supply is necessary for the expression of the genetic potential of plants, especially in highly weathered soils, with low available nutrient content. The most important source of magnesium is dolomitic limestone, used for soil acidity reduction and calcium and magnesium supply. However, in specific soil conditions, the supply of magnesium is required exclusively, especially when $\mathrm{pH}$ correction is not necessary or calcium content is adequate or in excess. In this condition, few economically feasible options are available, and the use of limestone may cause calcium/magnesium disorders. Unbalanced rates may be induced by the exportation of nutrients by high yield crops, once magnesium exportation is higher than calcium in plants like corn, for instance. Recent studies showed that high yield hybrids export 0,03 kg of Ca and $0,8 \mathrm{~kg}$ of $\mathrm{Mg}$ for tonne of grain, an exportation ratio of $\mathrm{Mg} / \mathrm{Ca}$ of 27, approximately (Silva 2009). The most prominent alternative sources for the magnesium supply are the ultramafic rocks, formed by iron and magnesium minerals, and their metamorphic equivalents. Among the latter, the serpentinite group is a potential source due to the high magnesium content of the protolith (Bucher \& Grapes 2011). The use of 
serpentinites in agriculture has been studied for the past decades in temperate climate countries. Chittenden et al. (1967) studied the performance of serpentinites and of dunites as magnesium sources in New Zealand. McNaught et al. (1968) evaluated the effects of many magnesium fertilizers, including serpentinite, in the forage yield in New Zealand. Hanly et al. (2005) studied the effect of the use of serpentinite and of its products of acidification in pastures of New Zealand. Błońska et al. (2016) studied the effect of the use of serpentinite and of other nutrients in a pine forest in Poland. Serpentinite based commercial products are available abroad, e.g. the fertilizer supplier in New Zealand: http:// www.fertco.co.nz/products/magnesiumfertiliser-products/serpentinite. Some works have already been done in Brazil, aiming to evaluate the performance of the serpentinite as a silicate agromineral and magnesium fertilizer. Luz et al. (2010) analyzed the agricultural potential of the serpentinites in Brazil, mostly as a byproduct of mining activities. Carmignano (2014) evaluated the performance of serpentinite from Minas Gerais in soybean crops. Blaskowski et al. (2016) evaluated the agricultural potential of the materials on mining waste piles from chromite mining in Bahia, which are mainly composed of serpentinites and dunites. Alovisi (2018) studied the response of forages to the use of serpentinite as a source of silicon. The measured reserves of the industrial serpentinite rocks in Brazil are above 140 million t, and are concentrated in the States of Minas Gerais, Goiás and Paraná (DNPM 2010). In Minas Gerais, one of the main occurrences of the serpentinites is in the Córrego dos Boiadeiros Body (CBB), an association of metaultramafic and subordinated metamafic rocks, at the central area of the Quadrilátero Ferrifero (QF). The CBB is a maficultramafic intrusive body in the Rio das Velhas greenstone belt (Fernandes 2016). Laboratory analyses of samples from the Mostardas mine showed that serpentinite is composed of $39.9 \%$ of $\mathrm{MgO}$, mostly in the minerals lizardite (Mg3Si2O5(OH)4) and talc (Mg3Si4O10(OH)2), with the secondary minerals: chromite $\left(\mathrm{FeCr}_{2} \mathrm{O}_{4}\right.$ ) and magnetite $\left(\mathrm{Fe}_{3} \mathrm{O}_{4}\right)$ (Ferreira et al. 2019). This work aimed to evaluate the use of serpentinite as a soil remineralizer, as well as a magnesium fertilizer.

\section{MATERIALS AND METHODS}

The experiment was carried out in a greenhouse at Embrapa's experimental farm in Sete Lagoas - MG - Brazil (19²8.5' S, $44^{\circ} 11.7^{\prime} \mathrm{W}$ ). The experimental design was based on a completely randomized scheme, with seven treatments, two soils, two plant species and four replications (112 experimental units). Two soils with contrasting granulometry were selected: clayed Ustox (Latossolo Vermelho Amarelo distrófico - LVAd) and a Quartzipsamments (Neossolo Quatzarênico órtico - RQo). Both presented low exchangeable magnesium contents (Table I). The sandy soil is an almost pure quartzose sand (developed from the Espinhaço group quartzites), and the clayed soil is a highly weathered Oxisol, presumably dominated by gibbsite and kaolinite in the clay fraction (based on similar soils of the region, e.g. De Brito Galvão \& Schulze 1996), from a metapelitic parental rock of the Bambui group. Two plant species were used: corn, hybrid BRS - 1055 and common bean, variety BRS - Estilo. The mining company Pedras Congonhas Ltda supplied the serpentinite and the phonolite rock powders. The serpentinite came from the "Mostarda" Mine in Nova Lima - MG, located on the Rio das Velhas greenstone belt. The main chemical elements of this rock are silicon $\left(\mathrm{SiO}_{2} 38.3 \%\right)$, magnesium ( $\mathrm{MgO} 39.9 \%$ ), iron $\left(\mathrm{Fe}_{2} \mathrm{O}_{3} 7.8 \%\right)$ and aluminum 
Table I. Soil Fertility and textural analyses of the soils used in the experiments*.

\begin{tabular}{|c|c|c|c|c|c|c|c|c|c|c|}
\hline Soil & $\mathrm{pH}$ & $\mathrm{H}+\mathrm{Al}$ & \multirow{2}{*}{\multicolumn{2}{|c|}{$\begin{array}{c}\text { P Mehlich-1 } \\
\text { mg/dm }\end{array}$}} & Al & $\mathrm{Ca}$ & Mg & $\mathbf{K}$ & SB & CEC \\
\hline & & $\mathrm{cmol}_{\mathrm{c}} / \mathrm{dm}^{3}$ & & & \multicolumn{6}{|c|}{ 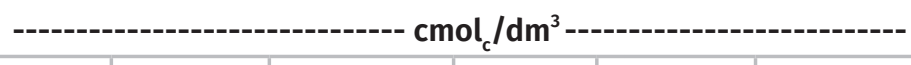 } \\
\hline RQo & 5.3 & 1.0 & \multicolumn{2}{|c|}{0.3} & 0.11 & 0.30 & 0.08 & 0.03 & 0.41 & 1.37 \\
\hline \multirow[t]{3}{*}{ LVAd } & 5.3 & 5.8 & & & 0.58 & 0.48 & 0.09 & 0.05 & 0.85 & 6.69 \\
\hline & \multicolumn{10}{|c|}{ Granulometric analysis of the Fine Earth ( $\mathrm{g} / \mathrm{kg}$ ) } \\
\hline & \multicolumn{3}{|c|}{ Coarse Sand 2-0.2 (mm) } & \multicolumn{3}{|c|}{ Fine Sand $0.20-0.05(\mathrm{~mm})$} & \multicolumn{2}{|c|}{ Silt 0.05-0.002 (mm) } & \multicolumn{2}{|c|}{ Clay $<0.002(\mathrm{~mm})$} \\
\hline LVAd & \multicolumn{3}{|c|}{70} & \multicolumn{3}{|c|}{30} & \multicolumn{2}{|c|}{80} & \multicolumn{2}{|c|}{820} \\
\hline RQo & \multicolumn{3}{|c|}{20} & \multicolumn{3}{|c|}{680} & \multicolumn{2}{|c|}{280} & \multicolumn{2}{|c|}{20} \\
\hline
\end{tabular}

(*) analyses according to the official soil methods (Teixeira et al. 2017).

$\left(\mathrm{AlO}_{2} 1.7 \%\right)$, and the dominant minerals are lizardite and talc, with minor chromite and magnetite (Ferreira et al. 2019). The phonolite is from the Curimbaba mining company in the Poços de Caldas Alkaline Complex (Alves 2003). Its chemical composition is $\mathrm{SiO}_{2}(53.4 \%), \mathrm{Al}_{2} \mathrm{O}_{3}$ (22.6\%), $\mathrm{K}_{2} \mathrm{O}(6.9 \%), \quad \mathrm{Na}_{2} \mathrm{O}(7.8 \%), \mathrm{Fe}_{2} \mathrm{O}_{3}(4.8 \%)$, $\mathrm{CaO}(1.4 \%)$ and $\mathrm{MgO}(0.16 \%)$. The main minerals are microcline, orthoclase, andalusite, nepheline and andesine (Teixeira et al. 2012). The mix of the phonolite to the serpentinite aimed to increase the total $\mathrm{K}$ content in the final product, to fulfill the remineralizer legislation demands (MAPA 2016). The calcitic and the dolomitic limestone in powder and the fertilizers were commercial grade products. The limestone doses were equivalent to $5.0 \mathrm{Mg} / \mathrm{ha}$ for the LVAd soil, and to $2.0 \mathrm{Mg} / \mathrm{ha}$ for the RQo soil, accordingly to Minas Gerais State recommendations (Alvarez \& Ribeiro 1999). Before planting, fertilizers were applied and mixed to the soils as follow: LVAd soil - urea (40 kg N/ha), superphosphate (240 kg $\left.\mathrm{P}_{2} \mathrm{O}_{5} / \mathrm{ha}\right), \mathrm{KCl}\left(200 \mathrm{~kg} \mathrm{~K} \mathrm{O}_{2} / \mathrm{ha}\right)$ plus the micronutrients source (100 kg FTE-BR12/ha), and RQo soil - urea (40 kg N/ha), superphosphate (120 kg $\left.\mathrm{P}_{2} \mathrm{O}_{5} / \mathrm{ha}\right), \mathrm{KCl}\left(100 \mathrm{~kg} \mathrm{~K} \mathrm{O}_{2} / \mathrm{ha}\right)$ plus the micronutrients source (100 kg FTE-BR12/ha). After that, 5-liter pots were filled with the soils. An additional urea dose was supplied 20 days after the germination, equivalent to $100 \mathrm{~kg}$ of
$\mathrm{N} /$ ha. The treatments were: 1 - Control without serpentinite, limestone or fertilizers (TEST); 2 - Control without serpentinite plus dolomitic limestone and fertilizers (the doses were accordingly to soil fertility analysis) (CALC_D); 3 - Control without serpentinite and with calcitic limestone and fertilizers (CALC_C); 4 - Treatment with serpentinite (dose 2) plus phonolite (3:1 in dry weight), plus calcitic limestone and fertilizers (SERP_F); 5 - Treatment with serpentinite (dose 1) plus calcitic limestone and fertilizers (SERP_D1); 6 - Treatment with serpentinite (dose 2) plus calcitic limestone and fertilizers (SERP_D2); 7 - Treatment with serpentinite (dose 3) plus calcitic limestone and fertilizers (SERP_D3). The doses applied are in the Table II. The serpentinite doses were equivalent to the nominal MgO content (14\%) in the reference (CALC_D), so that the dose 1 is equivalent to half the required dose of limestone, the dose 2 is equivalent to the full limestone dose, and the dose 3 is equivalent to one and a half the limestone dose. The pots were saturated with deionized water before being sown and kept close to the field capacity throughout the experiment. Based on previous tests, the amount of applied water was selected to be just enough to keep the soil moisture constant and to avoid leaching of excess water. Three seeds were used for each pot, and the plantlets were 
Table II. Values of applied doses of the minerals for the pot essay.

\begin{tabular}{|c|c|c|c|c|c|}
\hline \multirow{2}{*}{ Treatments } & & \multicolumn{3}{c|}{ Equivalent dose (T/ha) } \\
\cline { 2 - 6 } & Soil & $\begin{array}{c}\text { Dolomitic } \\
\text { limestone }\end{array}$ & $\begin{array}{c}\text { Calcitic } \\
\text { limestone }\end{array}$ & Serpentinite+Phonolite & Serpentinite \\
\hline Control & LVAd & 0.0 & 0.0 & 0.0 & 0.0 \\
\hline Dolomitic limestone & LVAd & 5.0 & 0.0 & 0.0 & 0.0 \\
\hline Calcitic limestone & LVAd & 0.0 & 5.0 & 0.0 & 0.0 \\
\hline Serpent. + Phonol. + Calc. Limest. & LVAd & 0.0 & 5.0 & 3.1 & 0.0 \\
\hline Serpentinite + Calc. limest. dose 01 & LVAd & 0.0 & 5.0 & 0.0 & 1.2 \\
\hline Serpentinite + Calc. limest. dose 03 & LVAd & 0.0 & 5.0 & 0.0 & 2.3 \\
\hline Control & RQO & 0.0 & 0.0 & 0.0 & 3.5 \\
\hline Dolomitic limestone & RQO & 2.0 & 0.0 & 0.0 & 0.0 \\
\hline Calcitic limestone & RQO & 0.0 & 2.0 & 0.0 & 0.0 \\
\hline Serpent. + Phonol. + Calc. Limest & RQO & 0.0 & 2.0 & 0.0 & 0.0 \\
\hline Serpentinite + Calc. limest. dose 01 & RQO & 0.0 & 2.0 & 1.2 & 0.0 \\
\hline Serpentinite + Calc. limest. dose 02 & RQO & 0.0 & 2.0 & 0.0 & 0.5 \\
\hline Serpentinite + Calc. limest. dose 03 & RQO & 0.0 & 2.0 & 0.0 & 0.9 \\
\hline
\end{tabular}

kept until the harvest of the plants. After 40 days of growth, the whole plants (above ground) were harvested and packed in paper bags, sent to oven dry at $60^{\circ} \mathrm{C}$ to measure the dry weight and ground in a rotary mill for the chemical analyses. The soil from each pot was sampled air dried and sieved in a $2.0 \mathrm{~mm}$ sieve and sent for the fertility analyses. The serpentinite and the mixture serpentinite/phonolite were analyzed according to the EPA 5032 reference method for the semi-total element content of the oxides of $\mathrm{K}, \mathrm{Ca}, \mathrm{Mg}, \mathrm{B}, \mathrm{Zn}, \mathrm{Cu}, \mathrm{Fe}, \mathrm{Mn}, \mathrm{Mo}, \mathrm{Co}, \mathrm{Ni}, \mathrm{Se}, \mathrm{Cl}$, As, $\mathrm{Cd}$ and $\mathrm{Pb}$, according to the EPA 7074-A reference method for the semi-total element content of $\mathrm{Hg}$. The reference methods referred at the INSDA No003/2015 MAPA (Cap I - B and Cap V) were followed for the granulometric analysis of the ground materials. A petrographic thin section of the serpentinite rock was evaluated by optical microscopy to measure the free silica content. The test was performed to fulfill the legal requirements. The legislation is vague concerning this issue (both the nature of the 'free' silica and the method to be used) and leaves to the researcher the choice of the method. The analysis was performed by point counting in the thin section, which is presumably to count basically the quartz grains. Nevertheless, this type of rock is not supposed to bear quartz, as is a metamorphosed peridotite. The soil samples and the plant materials were analyzed by the standard fertility methods and granulometric analysis (Silva 2009). The $\mathrm{pH}$ was measured in a soil/water proportion of 1:2.5. The exchangeable cations ( $\mathrm{Ca}, \mathrm{Mg}$ and $\mathrm{Al}$ ) were extracted with the 1 $\mathrm{M} \mathrm{KCl}$ solution. The Mehlich 1 solution was used for the extraction of $\mathrm{P}, \mathrm{K}$ and the micronutrients. The exchangeable acidity $\left(\mathrm{H}^{+}+\mathrm{Al}^{3+}\right)$ was extracted with the calcium acetate solution $(0.5 \mathrm{M})$. The plant analysis was done by the wet acid method (hot concentrated solution of $\mathrm{HNO}_{3}+\mathrm{HClO}_{4}$ 3:1, Silva 2009). The results were subjected to the statistical analyses using the R system's (R Core Team 2018) packages "MASS" (Venables \& Ripley 2002) and "agricolae" (Mendiburu 2017). 


\section{RESULTS AND DISCUSSION}

The petrographic analysis of the rock indicated that the free silica content (as quartz) is less than $5 \%$, which is below the maximum value of $25 \%$, by the legislation (MAPA 2016). Results of the semi-total element content are presented in the Table III. The serpentinite powder had high magnesium content (>38\% MgO), and low $\mathrm{K}$ and $\mathrm{Ca}$ content, but the sum of the bases ( $\mathrm{CaO}, \mathrm{MgO}$, $\mathrm{K}_{2} \mathrm{O}$ ) was above $39 \%$, higher than the minimum requirement in the legislation (9\%). Higher potential as source of boron (0.7\%) and cobalt (68 mg/ kg) was also evidenced. The potentially toxic elements ( $\mathrm{As}, \mathrm{Cd}, \mathrm{Hg}$ and $\mathrm{Pb}$ ) were all below the maximum levels established by the law (MAPA 2016), and below the detection limits of the method (Table III). Thus, the material is safe for use in agriculture as a silicate agromineral. Also, other elements, such as $\mathrm{Cu}, \mathrm{Zn}, \mathrm{Mn}$ and $\mathrm{Ni}$, for which no limit is established, did not present levels that indicate potential risks for agricultural use. The mix of serpentinite and phonolite produced a material with element contents very similar to the pure serpentinite powder (Table IV), but with higher $\mathrm{K}$ content ( $>2 \%$ ) and lower content of $\mathrm{Mg}$ and of the rest of the elements, by dilution. The mix product's $\mathrm{K}$ content was above the minimum requirement of the law, 1\% (MAPA 2016), and it was the only nutrient that had a higher total content after the mixing. The mix fitted the granulometric requirements of the law to be used as a powder (Table III). The pot soil analyses indicated that the fertilization was effective to raise the nutritional status and the soil's pH. The exchangeable contents of the Ca, K and sum of bases were higher than the control (TEST) in both soils. The differences between the soils are related to the initial contents, granulometry and mineralogy. There was no statistically significant effect on phonolite application (treatment SERP_F) in the $\mathrm{K}$ exchangeable content, compared to the treatments without phonolite (Tables $\mathrm{V}$ and $\mathrm{VI}$ ). This result is in accordance with the expected low solubility of the $\mathrm{K}$ sources in the minerals of this rock, regarding the short time of experiment and despite the use of a strong acid extraction solution for the analysis (Mehlich 1). The mix of the phonolite reduced the total content of the nutrients without any evident benefit to their availability (Table IV). The treatments with the same dose of serpentinite (treatment SERP_F and treatment SERP_D2), with the sole difference of the phonolite input in the former, statistically did not differ overall, including the soil fertility parameters and the total plant dry matter weight production (Tables V, VI, VII and VIII). These results indicated that its use did not have any practical effect in the short time range and the mix only increases the costs of production and freight per unit of the nutrients per tonne of product. Potential long term benefits could not be accessed by this experiment. The $\mathrm{pH}$ in water and the exchangeable acidity results (Tables $\mathrm{V}$ and $\mathrm{VI}$ ) showed the effect of the liming on the soils. The lower elevation of the $\mathrm{pH}$ in the LVAd soil, compared to the RQo soil, is related to its higher buffering capacity due to the greater clay content (82\%). There was statistically significant effect of the treatments on the $\mathrm{pH}$ results, without a clear pattern. The exchangeable Mg content was not statistically different among treatments with serpentinite, with calcitic limestone and the control TEST, but they were statistically different of the control CALC_D. This result is expected as the rock powders are less soluble than the limestone and the time span of the experiment was not long enough to allow the biochemical reactions that release the $\mathrm{Mg}$ of the minerals (Crawford et al. 2000) to reach the same level produced by the ready soluble carbonate. This result is also coherent with the $\mathrm{Mg}$ extraction by the plants. The doses of the 
Table III. Chemical analyses for semi-total element content and granulometric analysis of the serpentinite in powder.

\begin{tabular}{|c|c|c|c|c|c|}
\hline Parameter & Result & Unit & Uncertainty & Q. L. ${ }^{2}$ & Reference $^{1}$ \\
\hline pH 1:10 & 8.52 & - & 0.26 & 1 a 13 & NA \\
\hline Potash - $\mathrm{K}_{2} \mathrm{O}(\mathrm{HF})$ & $<1$ & $\%$ & 1 & - & $1 \mathrm{~min}$. \\
\hline Calcium Oxide (CaO) - (HF) & 0.95 & $\%$ & 0.03 & 0.5 & NA \\
\hline Magnesium Oxide (MgO) - (HF) & 38.20 & $\%$ & 1.15 & 0.5 & NA \\
\hline Boron - B (HF) & 0.7 & $\%$ & - & 0.1 & * \\
\hline Zinc - Zn (HF) & $<0.05$ & $\%$ & - & 0.05 & * \\
\hline Copper - Cu (HF) & $<0.05$ & $\%$ & - & 0.05 & * \\
\hline Iron - Fe (HF) & 5.54 & $\%$ & 0.17 & 0.05 & * \\
\hline Manganse - Mn (HF) & 0.09 & $\%$ & - & 0.05 & * \\
\hline Molybdenum Total - Mo (HF) & $<0.2$ & $\%$ & - & 0.01 & * \\
\hline Cobalt - Co (HF) & 66.82 & $\mathrm{mg} / \mathrm{kg}$ & 2 & 0.01 & * \\
\hline Nickel - Ni (HF) & 895 & $\mathrm{mg} / \mathrm{kg}$ & 27 & 0.2 & * \\
\hline Selenium - Se (HF), & $<0.2$ & $\mathrm{mg} / \mathrm{kg}$ & - & 0.2 & * \\
\hline Chlorine - $\mathrm{Cl}$ & $<0.1$ & $\%$ & - & 0.1 & * \\
\hline Arsenic - As (HF) & $<0.2$ & $\mathrm{mg} / \mathrm{kg}$ & - & 0.20 & 15 max. \\
\hline Cadmium - Cd (HF) & $<0.2$ & $\mathrm{mg} / \mathrm{kg}$ & - & 0.20 & 10 max. \\
\hline Mercury - Hg (HF) & $<0.1$ & $\mathrm{mg} / \mathrm{kg}$ & - & 0.1 & 0.1 max. \\
\hline Lead - Pb (HF) & $<0.2$ & $\mathrm{mg} / \mathrm{kg}$ & - & 0.20 & 200 max. \\
\hline \multicolumn{2}{|l|}{ Parameter } & Result & Unit & Uncertainty & Q. L. \\
\hline \multicolumn{2}{|c|}{$\%$ of the sample passing the sieve $\mathrm{n} .04(4.75 \mathrm{~mm})$} & 100 & $\%$ & - & 1 \\
\hline \multicolumn{2}{|c|}{$\%$ of the sample passing the sieve n. $07(2.80 \mathrm{~mm})$} & 100 & $\%$ & - & 1 \\
\hline \multicolumn{2}{|c|}{$\%$ of the sample passing the sieve n.10 (2.00 mm) } & 100 & $\%$ & 1 & 1 \\
\hline \multicolumn{2}{|c|}{$\%$ of the sample passing the sieve $\mathrm{n} .20(0.85 \mathrm{~mm})$} & 100 & $\%$ & - & 1 \\
\hline \multicolumn{2}{|c|}{$\%$ of the sample passing the sieve $n .50(0.300 \mathrm{~mm})$} & 93.39 & $\%$ & 1,24 & 1 \\
\hline
\end{tabular}

${ }^{1}$ According to Instrução Normativa N $^{\circ} 5$ do MAPA de 10 de Março de 2016. ${ }^{2}$ Quantification limit. 
serpentinite were chosen to be equivalent to the ones expected to be use in real agronomic situations, and the reference methods for soil analyses may be underestimating the availability of the $\mathrm{Mg}$ from the lower solubility fertilizers, which is indicated by the plant dry matter production. The differences in exchangeable $\mathrm{Mg}$ content did not relate to the plant dry matter, which indicate that there was no limitation for the plant production. The results of the nutrient content in the plant dry matter of corn and common bean clearly indicated the effect of fertilizer use, compared to the control TEST (Tables IX and X). The effect depends on the nutrient and soil characteristics, and it should be pointed that both soils have no previous report of fertilization or liming, and both have originally very low Mg content (Table I). The values of the corn dry matter weight were statistically different for the controls CALC_D and CALC_C and for the control TEST, for the LVAd soil (Table VII). The control CALC_C did not differ from the treatment SERP_D2, but differed from the other treatments with serpentinite. For RQo soil, there was no statistically significant difference among treatments, except for the control TEST, which was statistically different of all but the control CALC_C. The values of the common bean dry matter weight were not statistically different, except for the control without fertilizer, for the LVAd soil (Table VIII). There were statistically significant differences for the RQo soil. The treatments control CALC_D, SERP_F and SERP_D1 did not differ, the four treatments with serpentinite (SERP_F, SERP_D1, SERP_D2 and SERP_D3) did not differ, the control CALC_C and the SERP_D3 did not differ, and the control TEST differed from the others treatments. The regression equations fitted for the effect of serpentinite dose in the dry matter weight indicated a trend for the increment of the plant weight with the applied dose, not significant at the probability of 5\% (Tables XI to XIV). The $\mathrm{K}$ content values in the corn dry matter weight were in excess to the recommended levels for the LVAd soil, except for the control TEST, which is below the recommendations (Gott et al. 2014). Only the control TEST was statistically different from the other treatments (Table X). For the RQo soil, the treatments were slightly below to adequate to the recommended levels and were not statistically different, but the absolute values for the control TEST were well below the recommended levels. The $K$ content values in the bean dry matter weight had a similar pattern to the corn results in the LVAd soil, accordingly to the recommendations (Rosolem \& Marubayashi 1994). There was no statistically significant difference among the treatments with fertilizers, and only the control TEST was statistically different. In the RQo soil, the treatment SERP_D2 and the control CALC_C had low $\mathrm{K}$ values and the control TEST died before the end of the experiment. There was no statistically significant difference in the $\mathrm{K}$ content in plant dry matter weight among the treatments with pure serpentinite (SERP_D1, SERP_D2 and SERP_D3) and serpentinite plus phonolite (SERP_F). It indicates that, under the experimental conditions, no practical result was observed and its use is not justified. The Mg content values in the corn dry matter weight were above the adequate recommended levels for all the treatments in the LVAd soil, except for the control TEST, which was considered deficient (Gott et al. 2014). Only the two extreme cases, the control TEST and the control CALC_D were statistically different from the rest of treatments (Tables IX and X). For the RQo soil, the same trend was observed, but only the control CALC_D was statistically different from the rest of treatments. The $\mathrm{Mg}$ content values in the common bean dry matter weight were in the medium level class for the serpentinite 
Table IV. Chemical analyses for semi-total element content of the mix serpentinite plus phonolite (3:1) in powder.

\begin{tabular}{|c|c|c|c|c|c|}
\hline Parameter & Result & Unit & Uncertainty & Q. L. ${ }^{2}$ & Reference $^{1}$ \\
\hline $\mathrm{pH} 1: 10$ & 8.52 & - & 0.26 & 1 a 13 & NA \\
\hline Potash - K2O (HF) & 2.1 & $\%$ & _- & 1 & $1 \mathrm{~min}$. \\
\hline Calcium Oxide (CaO) - (HF) & 0.93 & $\%$ & 0.03 & 0.5 & NA \\
\hline Magnesium Oxide (MgO) - (HF) & 27.35 & $\%$ & 1.15 & 0.5 & NA \\
\hline Boron - B (HF) & 0.6 & $\%$ & - & 0.1 & * \\
\hline Zinc - Zn (HF) & $<0.05$ & $\%$ & - & 0.05 & * \\
\hline Copper - Cu (HF) & $<0.05$ & $\%$ & - & 0.05 & * \\
\hline Iron - Fe (HF) & 6.77 & $\%$ & 0.17 & 0.05 & * \\
\hline Manganse - Mn (HF) & 0.12 & $\%$ & - & 0.05 & * \\
\hline Molybdenum Total - Mo (HF) & $<0.2$ & $\%$ & - & 0.01 & * \\
\hline Cobalt - Co (HF) & 50.55 & $\mathrm{mg} / \mathrm{kg}$ & 2 & 0.01 & * \\
\hline Nickel - Ni (HF) & 857 & $\mathrm{mg} / \mathrm{kg}$ & 27 & 0.2 & * \\
\hline Selenium (Se) - (HF) & $<0.2$ & $\mathrm{mg} / \mathrm{kg}$ & - & 0.2 & * \\
\hline Chlorine - $\mathrm{Cl}$ & $<0.1$ & $\%$ & - & 0.1 & * \\
\hline Arsenic - As (HF) & $<0.2$ & $\mathrm{mg} / \mathrm{kg}$ & - & 0.20 & 15 max. \\
\hline Cadmium - Cd (HF) & $<0.2$ & $\mathrm{mg} / \mathrm{kg}$ & - & 0.20 & 10 max. \\
\hline Mercury - Hg (HF) & $<0.1$ & $\mathrm{mg} / \mathrm{kg}$ & - & 0.1 & $0.1 \max$ \\
\hline Lead - Pb (HF) & $<0.2$ & $\mathrm{mg} / \mathrm{kg}$ & - & 0.20 & 200 max. \\
\hline
\end{tabular}

${ }^{1}$ According to Instrução Normativa № 5 do MAPA, de 10 de Março de 2016. ${ }^{2}$ Quantification limit.

treatments, they were in the low class for the control CALC_C and the control TEST, and the control CALC_D was above the adequate recommended levels in the LVAd soil. The latter was the only statistically different from all the others. For the RQo soil, the control CALC_D was above the adequate recommended levels, the treatments SERP_D3 and SERP_F were in the medium class and the rest were in the low class. The control CALC_D was the only statistically different from all the others. These results are coherent with the soil exchangeable $\mathrm{Mg}$ results, discussed above.

In their work, comparing the effect of $\mathrm{Mg}$ fertilization in five common bean varieties, Canizella et al. (2015) reported that the BRS
Estilo was included in the group of varieties with the greatest content of $\mathrm{Mg}$, regardless of the rate applied. There was no effect of the type of $\mathrm{Mg}$ source in the plant dry matter weight, and this element was not the limiting factor. The corn plant dry matter weight of the treatments with serpentinite (SERP_F, SERP_D1 and SERP_D2 and SERP_D3) were not statistically different from the control CALC_D. The higher Mg plant content in the control CALC_D may be attributed to the luxury consumption of this nutrient, as its content is 3 times the content of the treatment with serpentinite (Table IX), and well above the recommended content. Madhok \& Walker (1969) reported the luxury consumption of Mg by common sunflower in nutrient solution, with 
Table V. Content of potassium and magnesium in soils cultivated with corn. (The means of four replicates followed by the same letters in columns are not statistically different at a probability of $5 \%$ ).

\begin{tabular}{|c|c|c|c|c|c|c|}
\hline Parameter & Treatments* & Soil LVAd & & Treatment $^{*}$ & Soil RQo & \\
\hline \multirow{7}{*}{$\mathrm{K}(\mathrm{mg} / \mathrm{kg})$} & Serp_F & 101.4 & $\mathrm{a}$ & Serp_F & 15.1 & a \\
\hline & Serp_D2 & 100.0 & $\mathrm{a}$ & Serp_D2 & 14.0 & $a b$ \\
\hline & Serp_D3 & 99.6 & $a$ & Serp_D1 & 12.8 & $a b$ \\
\hline & Calc_C & 87.4 & $\mathrm{a}$ & Calc_D & 12.0 & $a b$ \\
\hline & Serp_D1 & 82.5 & $a$ & Serp_D3 & 10.8 & $a b$ \\
\hline & Calc_D & 76.0 & $\mathrm{a}$ & Calc_c & 9.9 & $b$ \\
\hline & Test & 49.9 & $\mathrm{a}$ & Test & 9.8 & $b$ \\
\hline \multirow{7}{*}{$\mathrm{Mg}\left(\mathrm{cmol}_{\mathrm{c}} / \mathrm{dm}^{3}\right)$} & Calc_D & 1.65 & $\mathrm{a}$ & Calc_D & 0.38 & a \\
\hline & Serp_D1 & 0.20 & $b$ & Calc_C & 0.20 & $b$ \\
\hline & Serp_D2 & 0.20 & $b$ & Serp_D1 & 0.20 & $b$ \\
\hline & Serp_D3 & 0.20 & $\mathrm{~b}$ & Serp_D2 & 0.20 & $b$ \\
\hline & Test & 0.20 & $b$ & Serp_F & 0.20 & b \\
\hline & Calc_c & 0.18 & $\mathrm{~b}$ & Test & 0.20 & $b$ \\
\hline & Serp_F & 0.18 & $b$ & Serp_D3 & 0.16 & $b$ \\
\hline
\end{tabular}

(") Test: Control, Calc_D: Dolomitic limestone, Calc_C: Calcitic limestone, Serp_F: Serpentinite + phonolite (3:1) + Calcitic limestone, Serp_D1: Serpentinite + Calcitic limestone dose 01, Serp_D2: Serpentinite + Calcitic limestone dose 02, Serp_D3: Serpentinite + Calcitic limestone dose 03.

Table VI. Content of potassium and magnesium in soils cultivated with common bean. The means of four replicates followed by the same letters in columns are not statistically different at a probability of $5 \%$.

\begin{tabular}{|c|c|c|c|c|c|c|}
\hline Parameter & Treatment $^{*}$ & Soil LVAd & & Treatment $^{*}$ & Soil RQo & \\
\hline \multirow{7}{*}{$\mathrm{K}(\mathrm{mg} / \mathrm{kg})$} & Serp_F & 177.5 & $\mathrm{a}$ & Serp_F & 20.5 & a \\
\hline & Serp_D2 & 167.3 & $\mathrm{a}$ & Serp_D3 & 20.2 & $\mathrm{a}$ \\
\hline & Serp_D1 & 160.9 & $\mathrm{a}$ & Serp_D1 & 18.3 & $a b$ \\
\hline & Calc_C & 152.4 & $\mathrm{a}$ & Calc_C & 18.2 & $a b$ \\
\hline & Serp_D3 & 137.5 & $\mathrm{a}$ & Serp_D2 & 15.2 & $a b c$ \\
\hline & Calc_D & 134.5 & $\mathrm{a}$ & Calc_D & 12.6 & $b c$ \\
\hline & Test & 25.1 & $b$ & Test & 11.1 & $\mathrm{C}$ \\
\hline \multirow{7}{*}{$\operatorname{Mg}\left(\mathrm{cmol}_{\mathrm{c}} / \mathrm{dm}^{3}\right)$} & Calc_D & 1.45 & $\mathrm{a}$ & Calc_D & 0.33 & a \\
\hline & Serp_F & 0.20 & $\mathrm{~b}$ & Calc_C & 0.16 & $b$ \\
\hline & Serp_D1 & 0.20 & $\mathrm{~b}$ & Serp_D1 & 0.16 & $b$ \\
\hline & Serp_D3 & 0.20 & $b$ & Serp_D2 & 0.16 & $b$ \\
\hline & Serp_D2 & 0.20 & $\mathrm{~b}$ & Serp_D3 & 0.16 & $b$ \\
\hline & Test & 0.20 & $\mathrm{~b}$ & Serp_F & 0.16 & $b$ \\
\hline & Calc_C & 0.18 & $\mathrm{~b}$ & Test & 0.16 & $b$ \\
\hline
\end{tabular}

(*) Test: Control, Calc_D: Dolomitic limestone, Calc_C: Calcitic limestone, Serp_F: Serpentinite + phonolite (3:1) + Calcitic limestone, Serp_D1: Serpentinite + Calcitic limestone dose 01, Serp_D2: Serpentinite + Calcitic limestone dose 02, Serp_D3: Serpentinite + Calcitic limestone dose 03.

the internal content of $\mathrm{Mg}$ only correlating to the yield up to $0.20 \mathrm{mM}$ of $\mathrm{Mg}$ in solution. Above that level, there was a continuous increase in the internal Mg content per dry weight without additional increase in dry mass yield. 
Table VII. Weight dry matter of corn plants (g/pot). The means of four replicates followed by the same letters in columns are not statistically different at a probability of $5 \%$.

\begin{tabular}{|c|c|c|c|c|c|}
\hline Treatment $^{*}$ & \multicolumn{2}{|c|}{ Soil LVAd } & Treatment $^{*}$ & \multicolumn{2}{c|}{ Soil RQo } \\
\hline Calc_D & 2.30 & a & Calc_D & 1.68 & $\mathrm{a}$ \\
\hline Serp_D2 & 1.83 & $\mathrm{ab}$ & Serp_F & 1.43 & $\mathrm{a}$ \\
\hline Serp_D1 & 1.70 & $\mathrm{ab}$ & Serp_D3 & 1.30 & $\mathrm{a}$ \\
\hline Serp_D3 & 1.58 & $\mathrm{ab}$ & Serp_D2 & 1.25 & $\mathrm{a}$ \\
\hline Serp_F & 1.58 & $\mathrm{ab}$ & Calc_C & 1.08 & $\mathrm{ab}$ \\
\hline Calc_C & 1.45 & b & Serp_D1 & 1.08 & $\mathrm{ab}$ \\
\hline Test & 0.48 & c & Test & 0.28 & $\mathrm{~b}$ \\
\hline
\end{tabular}

( $\left.{ }^{\star}\right)$ Test: Control, Calc_D: Dolomitic limestone, Calc_C: Calcitic limestone, Serp_F: Serpentinite + phonolite (3:1) + Calcitic limestone, Serp_D1: Serpentinite + Calcitic limestone dose 01, Serp_D2: Serpentinite + Calcitic limestone dose 02, Serp_D3: Serpentinite + Calcitic limestone dose 03.

Table VIII. Weight dry matter of common bean plants (g/pot). (The means of four replicates followed by the same letters in columns are not statistically different at a probability of $5 \%$ ).

\begin{tabular}{|c|c|c|c|c|c|}
\hline Treatment $^{*}$ & \multicolumn{2}{|c|}{ Soil LVAd } & Treatment $^{*}$ & \multicolumn{2}{c|}{ Soil RQo $^{\text {( }}$} \\
\hline Serp_D2 & 0.98 & a & Calc_D & 0.78 & a \\
\hline Serp_D1 & 0.93 & a & Serp_D1 & 0.68 & ab \\
\hline Calc_C & 0.85 & a & Serp_F & 0.68 & ab \\
\hline Calc_D & 0.85 & a & Serp_D2 & 0.55 & abc \\
\hline Serp_D3 & 0.78 & a & Serp_D3 & 0.48 & bc \\
\hline Serp_F & 0.78 & a & Calc_C & 0.33 & cd \\
\hline Test & 0.43 & b & Test & 0.10 & d \\
\hline
\end{tabular}

(*) Test: Control, Calc_D: Dolomitic limestone, Calc_C: Calcitic limestone, Serp_F: Serpentinite + phonolite (3:1) + Calcitic limestone, Serp_D1: Serpentinite + Calcitic limestone dose 01, Serp_D2: Serpentinite + Calcitic limestone dose 02, Serp_D3: Serpentinite + Calcitic limestone dose 03.

Table IX. Content of potassium and magnesium in dry matter of corn plants. The means of four replicates followed by the same letters in columns are not statistically different at a probability of $5 \%$.

\begin{tabular}{|c|c|c|c|c|c|c|}
\hline \multirow[t]{2}{*}{ Element } & \multirow{2}{*}{$\begin{array}{c}\text { Treatment }^{*} \\
\text { Calc_D }\end{array}$} & \multicolumn{2}{|c|}{ Soil LVAd } & \multirow{2}{*}{$\begin{array}{c}\text { Treatment }^{*} \\
\text { Calc_D }\end{array}$} & \multicolumn{2}{|c|}{ Soil RQo } \\
\hline & & 17.54 & $\mathrm{a}$ & & 23.76 & $\mathrm{a}$ \\
\hline \multirow{6}{*}{$\operatorname{Mg}(\mathrm{g} / \mathrm{kg})$} & Serp_D3 & 5.70 & $b$ & Serp_D3 & 5.94 & $b$ \\
\hline & Serp_D2 & 5.09 & $b$ & Serp_F & 4.54 & $b$ \\
\hline & Serp_F & 4.48 & $b c$ & Serp_D2 & 4.40 & $b$ \\
\hline & Serp_D1 & 4.46 & $b c$ & Serp_D1 & 3.52 & $b$ \\
\hline & Calc_C & 2.67 & $\mathrm{~cd}$ & Calc_C & 2.89 & $b$ \\
\hline & Test & 1.28 & $d$ & Test & 0.59 & $b$ \\
\hline \multirow{7}{*}{$\mathrm{K}(\mathrm{g} / \mathrm{kg})$} & Calc_D & 154.05 & $a$ & Serp_D2 & 38.79 & $a$ \\
\hline & Serp_D3 & 139.25 & $a b$ & Serp_D1 & 25.38 & $a$ \\
\hline & Serp_F & 136.87 & $a b$ & Calc_D & 24.49 & a \\
\hline & Serp_D2 & 126.21 & $b c$ & Serp_D3 & 21.43 & a \\
\hline & Serp_D1 & 121.73 & $b c$ & Serp_F & 20.71 & a \\
\hline & Calc_C & 103.46 & $\mathrm{C}$ & Calc_C & 13.20 & a \\
\hline & Test & 11.94 & $d$ & Test & 1.46 & $a$ \\
\hline
\end{tabular}

(*) Test: Control, Calc_D: Dolomitic limestone, Calc_C: Calcitic limestone, Serp_F: Serpentinite + phonolite (3:1) + Calcitic limestone, Serp_D1: Serpentinite + Calcitic limestone dose 01, Serp_D2: Serpentinite + Calcitic limestone dose 02, Serp_D3: Serpentinite + Calcitic limestone dose 03. 
Table X. Content of potassium and magnesium in dry matter of common bean plants. The means of four replicates followed by the same letters in columns are not statistically different at a probability of $5 \%$.

\begin{tabular}{|c|c|c|c|c|c|c|}
\hline \multirow[t]{2}{*}{ Element } & \multirow{2}{*}{$\begin{array}{c}\text { Treatment }^{*} \\
\text { Calc_D }\end{array}$} & \multicolumn{2}{|c|}{ Soil LVAd } & \multirow{2}{*}{$\begin{array}{c}\text { Treatment }^{*} \\
\text { Calc_D }\end{array}$} & \multicolumn{2}{|c|}{ Soil RQo } \\
\hline & & 7.98 & $\mathrm{a}$ & & 10.85 & $\mathrm{a}$ \\
\hline \multirow{6}{*}{$M g(g / k g)$} & Serp_D2 & 2.62 & $b$ & Serp_F & 2.40 & $b$ \\
\hline & Serp_F & 2.52 & $b$ & Serp_D3 & 2.04 & $b$ \\
\hline & Serp_D3 & 2.46 & $b$ & Serp_D1 & 1.88 & $b$ \\
\hline & Serp_D1 & 2.06 & $b c$ & Serp_D2 & 1.78 & $b$ \\
\hline & Calc_C & 1.87 & $b c$ & Calc_C & 0.97 & $b$ \\
\hline & Test & 1.18 & $C$ & Test & 0.00 & $b$ \\
\hline \multirow{7}{*}{$\mathrm{K}(\mathrm{g} / \mathrm{kg})$} & Calc_C & 59.89 & $\mathrm{a}$ & Serp_D1 & 27.42 & a \\
\hline & Serp_D1 & 59.31 & $\mathrm{a}$ & Calc_D & 25.95 & $\mathrm{a}$ \\
\hline & Serp_D2 & 59.27 & $a$ & Serp_F & 23.96 & $a b$ \\
\hline & Serp_F & 58.03 & $\mathrm{a}$ & Serp_D3 & 21.06 & $a b$ \\
\hline & Calc_D & 57.01 & $\mathrm{a}$ & Serp_D2 & 16.30 & $a b c$ \\
\hline & Serp_D3 & 52.17 & $\mathrm{a}$ & Calc_c & 12.39 & $b c$ \\
\hline & Test & 9.94 & $b$ & Test & 0.00 & $\mathrm{C}$ \\
\hline
\end{tabular}

(*) Test: Control, Calc_D: Dolomitic limestone, Calc_C: Calcitic limestone, Serp_F: Serpentinite + phonolite (3:1) + Calcitic limestone, Serp_D1: Serpentinite + Calcitic limestone dose 01, Serp_D2: Serpentinite + Calcitic limestone dose 02, Serp_D3: Serpentinite + Calcitic limestone dose 03.

Table XI. ANOVA and parameters of the regression equation for serpentinite doses per pot (g) and plant total dry weight per pot (g) for corn pots in the soil LVAd.

\begin{tabular}{|c|c|c|c|c|c|}
\hline Parameter & Coeficient & Standard error & "t" value & Probability (>|t|) & (\#) \\
\hline Intercept & 3.65734 & 0.38894 & 9.403 & 7.51E-10 & $* * *$ \\
\hline Dose/pot & 0.11403 & 0.06573 & 1.735 & 0.0946 & 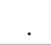 \\
\hline Degrees of freedom & Residual Standard error & Multiple $\mathrm{R}^{2}$ & Fitted $\mathrm{R}^{2}$ & & \\
\hline 26 & 1.444 & 0.1037 & 0.06927 & & \\
\hline F statistics & \multicolumn{2}{|c|}{ in Degrees of freedom } & $p$ value & & \\
\hline 3.009 & \multicolumn{2}{|c|}{1 and 26} & 0.0946 & & \\
\hline
\end{tabular}

${ }^{(\#)}$ Significance: $\left.{ }^{* * *}\right) 0.001()$.0.1 .

Table XII. ANOVA and parameters of the regression equation for serpentinite dose per pot (g) and plant total dry weight per pot (g) for corn pots in the soil RQo.

\begin{tabular}{|c|c|c|c|c|c|}
\hline Parameter & Coeficient & Standard error & "t" value & Probability $(>|t|)$ & (\#) \\
\hline Intercept & 2.2935 & 0.4783 & 4.795 & $5.78 \mathrm{E}-05$ & $* * *$ \\
\hline Dose/pot & 0.4008 & 0.2021 & 1.983 & 0.058 & \\
\hline Degrees of freedom & Residual Standard error & Multiple $\mathrm{R}^{2}$ & Fitted $\mathrm{R}^{2}$ & & \\
\hline 26 & 1.775 & 0.1314 & 0.098 & & \\
\hline F statistics & \multicolumn{2}{|c|}{ in Degrees of freedom } & $p$ value & & \\
\hline 3.933 & \multicolumn{2}{|c|}{1 and 26} & 0.058 & & \\
\hline
\end{tabular}

(\#)Significance: (***) 0.001 (.) 0.1 . 
Table XIII. ANOVA and parameters of the regression equation for serpentinite dose per pot (g) and plant total dry weight per pot (g) for common bean pots in the soil LVAd.

\begin{tabular}{|c|c|c|c|c|c|}
\hline Parameter & Coeficient & Standard error & "t" value & Probability (>|t|) & (\#) \\
\hline Intercept & 2.10629 & 0.15952 & 13.204 & 4.89E-13 & $\star \star \star *$ \\
\hline Dose/pot & 0.03594 & 0.02696 & 1.333 & 0.194 & \\
\hline Degrees of freedom & Residual Standard error & Multiple $\mathrm{R}^{2}$ & Fitted $\mathrm{R}^{2}$ & & \\
\hline 26 & 0.5921 & 0.06399 & 0.02798 & & \\
\hline F statistics & \multicolumn{2}{|c|}{ in Degrees of freedom } & p value & & \\
\hline 1.777 & \multicolumn{2}{|c|}{1 and 26} & 0.194 & & \\
\hline
\end{tabular}

(\#)Significance: $(* * *) 0.001$.

Table XIV. ANOVA and parameters of the regression equation for serpentinite dose per pot (g) and plant total dry weight per pot (g) for common bean pots in the soil RQo.

\begin{tabular}{|c|c|c|c|c|c|}
\hline Parameter & Coeficient & Standard error & "t" value & Probability (>|t|) & (\#) \\
\hline Intercept & 1.0795 & 0.2171 & 4.972 & 4.01E-05 & $\star \star \star *$ \\
\hline Dose/pot & 0.6037 & 0.2968 & 2.034 & 0.0527 & . \\
\hline$(\text { Dose } / \text { pot })^{2}$ & -0.1264 & 0.0727 & -1.738 & 0.0945 & . \\
\hline Degrees of freedom & Residual Standard error & Multiple $\mathrm{R}^{2}$ & Fitted $\mathrm{R}^{2}$ & & \\
\hline 25 & 0.7607 & 0.1565 & 0.08906 & & \\
\hline F statistics & \multicolumn{2}{|c|}{ in Degrees of freedom } & $p$ value & & \\
\hline 0.1565 & \multicolumn{2}{|c|}{1 and 26} & 0.1191 & & \\
\hline
\end{tabular}

(\#)Significance: $(* * *) 0.001()$.0.1 .

\section{CONCLUSIONS}

Chemical and mineralogical analyses showed that the serpentinite presented high total MgO contents. The free silica and the potentially toxic elements ( $\mathrm{As}, \mathrm{Cd}, \mathrm{Hg}$ and $\mathrm{Pb}$ ) contents are all below the legal requirements. Also, other measured elements, for which no limit is stipulated by law, presented no potential risks regarding its use. No statistically significant difference was reported from the plant dry matter weight of the evaluated plant species among the treatments with the use of the serpentinite and the control CALC_D. Differences among the treatments with the use of the serpentinite and the control CALC_D, compared to the control without fertilization, did occur.
On the other hand, the treatments with the use of the pure serpentinite and the mix with the phonolite presented similar behavior, as well as considering the plant dry matter weight and $\mathrm{Mg}$ content in the soil and plant dry matter weight. No loss or benefit could be inferred from the mix of the serpentinite with the phonolite, other than the reduction of the total nutrient content by dilution, with exception of the $\mathrm{K}$. The exchangeable $\mathrm{Mg}$ in the soil and the $\mathrm{Mg}$ in the plant dry matter weight were statistically different only for the control treatment with the use of the dolomitic limestone, compared to all the others. This difference was not related to the plant dry weight, for common bean and for corn. It is inferred that the tested remineralizers 
(pure serpentinite and the mix with phonolite), were able to supply the $\mathrm{Mg}$ and to fulfil the plant requirements, and the higher plant $\mathrm{Mg}$ content in the control with use of the dolomitic limestone was attributed to the luxury consumption of the element.

\section{Acknowledgments}

This work was done under the auspices of the cooperation project among EMBRAPA, Fundação de Apoio à Pesquisa e Desenvolvimento (FAPED), Universidade Federal de São João del-Rei and Pedras Congonhas Arte Indústria Ltda, with code number 20700.18/0037-3 and register code FAPED 402.

\section{REFERENCES}

ALOVISI AA. 2018. Silicato de magnésio e bioativador na produtividade de Urochloa e de trigo. Dissertação (Mestrado Programa de Pós-Graduação em Agronomia). Universidade Federal da Grande Dourados, Dourados, 69 p. (Unpublished).

ALVAREZ VVH \& RIBEIRO AC. 1999. Calagem. In: Ribeiro AC, Guimarães PTG and Alvarez VVH (Eds). Recomendações para o uso de corretivos e fertilizantes em minas gerais: 5a aproximação. Viçosa, MG: Comissão de Fertilidade do Solo do Estado de Minas Gerais, p. 43-60.

ALVES AD. 2003. Rochas Vulcanoclásticas do Complexo Alcalino de Poços de Caldas - MG/SP. Dissertação (Mestrado em Mineralogia e Petrologia) - Instituto de Geociências, Universidade de São Paulo, São Paulo, 2003. doi:10.11606/D.44.2003.tde-02042014-104025. (Unpublished).

BLASKOWSKI AE, BERGMANN M, SILVEIRA CAP, GARNIER J, CAMARGO MA \& CAVALCANTE OA. 2016. Potencial das rochas das pilhas de rejeitos da mineração Ferbasa-Cia de Ferroligas da Bahia como corretivos e remineralizadores de solo. p. 121-127. In: Anais do III Congresso Brasileiro de Rochagem, 8 a 11 de novembro de 2016 / Adilson Luis Bamberg... et. al. (Eds). Pelotas: Embrapa Clima Temperado; Brasilia: Embrapa Cerrados; Assis: Triunfal Gráfica e Editora, 455 p. : il. ISBN: 978-85-61175-68-9.

BŁOŃSKA E, JANUSZEK K, MAŁEK S \& WANIC T. 2016. Effects of serpentinite fertilizer on the chemical properties and enzyme activity of young spruce soils. Int Agrophys 30: 401-414. DOI: 10.1515/intag-2016-0015.
BUCHER CK \& GRAPES R. 2011. Petrogenesis of Metamorphic Rocks. Springer-Verlag: Berlin Heidelberg, 428 p.

CANIZELLA BT, MOREIRA A, MORAES LA C \& FAGERIA NK. 2015. Efficiency of magnesium use by common bean varieties regarding yield, physiological components, and nutritional status of plants. Commun Soil Sci Plant Anal 46(11): 1376-1390. DOI: 10.1080/00103624.2015.1043452.

CARMIGNANO ORDR. 2014. Avaliação do comportamento do serpentinito na cultura da soja. 71 f. Dissertação (Mestrado em Sustentabilidade Socioeconômica Ambiental). Universidade Federal de Ouro Preto: Ouro Preto. (Unpublished).

CHITTENDEN ET, STANTON DJ, WATSON J \& DODSON KJ. 1967. Serpentine and dunite as magnesium fertilisers. New Zealand J Agric Res 10(1): 160-171. DOI: 10.1080/00288233 .1967.10423088.

CRAWFORD RH, FLOYD M \& LI CY. 2000. Degradation of serpentine and muscovite rock minerals and immobilization of cations by soil Penicillium spp. Phyton 40(2): 315-322.

DE BRITO GALVÃO TC \& SCHULZE DG. 1996. Mineralogical properties of a collapsible lateritic soil from Minas Gerais, Brazil. Soil Sci Soc Am J 60: 1969-1978.

DNPM. 2010. Anuário Mineral Brasileiro. vol. 35. Brasília: Departamento Nacional de Produção Mineral, 871 p.

FERNANDES VMT. 2016. Petrogênese e Geoquímica de rochas Metaultramáficas e Máficas do corpo Córrego dos Boiadeiros, Grupo Nova Lima, Quadrilátero Ferrífero, MG. 143 f. (Dissertação, Mestrado em Ciências Naturais, Área de Concentração: Tectônica, Petrogênese e Recursos Minerais). Escola de Minas UFOP, Departamento de Geologia, Ouro Preto. (Unpublished).

FERREIRA L, BRANDÃO PRG \& CARMIGNANO ORDR. 2019. Caracterização de serpentinito antes e após calcinação a $1200{ }^{\circ} \mathrm{C}$. Tecnol Metal Mater Miner 16(3): 363-369. https:// doi.org/10.4322/2176-1523.20191785.

GOTT RM, AQUINO LA, CARVALHO AMX, SANTOS LPD, NUNES PHMP \& COELHO BS. 2014. Índices diagnósticos para interpretação de análise foliar do milho. Rev Bras Eng Agríc Ambient 18(11): 1110-1115. DOI 10.1590/1807-1929

HANLY JA, LOGANATHAN P \& CURRIE LD. 2005. Effect of serpentine rockand its acidulated products as magnesium fertilisers for pasture, compared with magnesium oxide and Epsom salts, on a Pumice Soil. 1. Dry matter yield and magnesium uptake. New Zealand J Agric Res 48(4): 451-460. DOI: 10.1080/00288233.2005.9513679.

HAWKESFORD M, HORST W, KICHEY T, LAMBERS H, SCHJOERRING J, M $\varnothing$ LLER IS \& WHITE P. 2012. Chapter 6 - Functions of 
Macronutrients. In: Marschner's Mineral Nutrition of Higher Plants ( $3^{\text {rd }}$ Edition). Edited by Petra Marschner: Academic Press, San Diego, p. 135-189.

LUZ AB, LOUREIRO FEL, SAMPAIO JA, CASTILHOS ZC \& BEZERRA MS. 2010. Capítulo 4. Rochas, minerais e rotas tecnológicas para a produção de fertilizantes alternativos. In: Centro de Tecnologia Mineral. Agrominerais para o Brasil/ Francisco R. C. Fernandes, Adão B. da Luz \& Zuleica C. Castilhos eds. Rio de Janeiro: CETEM/MCT, 380 p.

MADHOK OP \& WALKER RB. 1969. Magnesium nutrition of two species of sunflower. Plant Physiology 44: 1016-1022.

MAPA. 2016. INSTRUÇÃO NORMATIVA № 5, DE 10 DE MARÇO DE 2016. Acesso em 20/09/2018: http://www.agricultura.gov. $\mathrm{br} /$ sislegis.

MCNAUGHT KJ, DOROFAEFF FD \& KARLOVSKY J. 1968. Effect of magnesium fertilisers and season on levels of inorganic nutrients in a pasture on Hamilton clay loam. New Zealand J Agric Res 11(3): 533-550.

MENDIBURU F. 2017. agricolae: Statistical Procedures for Agricultural Research. R package version 1.2-8. Acesso em 20/09/2018: https://CRAN.R-project.org/ package=agricolae.

R CORE TEAM. 2018. R: A language and environment for statistical computing. R Foundation for Statistical Computing, Vienna, Austria. Acesso em 20/09/2018: https://www.R-project.org/.

ROSOLEM CA \& MARUBAYASHI OM. 1994. Seja o doutor do seu feijoeiro. Arquivo do agrônomo - no 7 . Encarte do informações agronômicas 68: 1-4.

SILVA FC. 2009. Manual de Análises Químicas de Solos, Plantas e Fertilizantes, 2a ed. Brasília: Embrapa, 627 p.

TEIXEIRA AMS, SAMPAIO JA, GARRIDO FMS \& MEDEIROS ME. 2012. Avaliação da rocha fonolito como fertilizante alternativo de potássio. HOLOS 5: 21-33.

\section{How to cite}

VIANA JHM, COELHO AM, THOMAZINI A \& DE CARVALHO MPF. 2021. Evaluation of the agricultural potential of the serpentinite rock as a soil remineralizer. An Acad Bras Cienc 93: e20201614. DOI 10.1590/00013765202120201614 .

Manuscript received on October 15, 2020;

accepted for publication on December 27, 2020
JOÃO H.M. VIANA ${ }^{1}$

https://orcid.org/0000-0002-5872-4816

\section{ANTÔNIO M. COELHO ${ }^{1}$}

https://orcid.org/0000-0002-2822-5012

\section{ANDRÉ THOMAZINI ${ }^{2}$}

https://orcid.org/0000-0001-5613-0494

\section{MATHEUS P.F. DE CARVALHO ${ }^{2}$}

https://orcid.org/0000-0002-8207-9706

${ }^{1}$ Embrapa Milho e Sorgo, Rodovia MG-424, Km 45, Caixa

Postal 285, 35701-970 Sete Lagoas, MG, Brazil

${ }^{2}$ Universidade de São João Del Rey, Departamento de Ciências Agrárias/DCIAG, Rua Sétimo Moreira Martins, 188, Itapoã, Caixa Postal 56, 35702-031 Sete Lagoas, MG, Brazil

Correspondence to: João H. M. Viana

E-mail: joao.herbert@embrapa.br

\section{Author contributions}

JHMV, AMC and AT conceived and planned the experiment. JHMV, AT and MPFC carried out the experiment. JHMV and AT supervised the experiment. JHMV processed the experimental data, performed the statistical analysis and took the lead in writing the manuscript. All authors discussed the results and commented on the manuscript.

\section{(cc) BY}

